\title{
MARGINALISM AND SCOPE IN THE EARLY METHODENSTREIT
}

\author{
BY JENS VAN'T KLOOSTER*
}

\begin{abstract}
Recent interpretations of the early Methodenstreit (1871 - 1883) between Gustav Schmoller and Carl Menger no longer identify a substantial point of controversy. I reconstruct the debate to show that the pivotal topic was the scope of economics. Menger claims that his Principles of Economics more or less capture the full scope of the discipline, which Schmoller denies. I also discuss recent Menger scholarship, which follows Friedrich Hayek in situating Menger at the edges or even outside the marginalist mainstream. I argue that this interpretation wrongly denies Menger his pioneer status as, possibly the first, marginalist.

* European University Institute, Social and Political Sciences.

Contact: jens.vantklooster@,kuleuven.be
\end{abstract}

This "preprint" is the peer-reviewed and accepted typescript of an article that is forthcoming in revised form, after minor editorial changes, in the Journal of the History of Economic Thought (ISSN: 1053-8372), issue TBA. Copyright to the journal's articles is held by the History of Economics Society (HES), whose exclusive licensee and publisher for the journal is Cambridge University Press.

(https://www.cambridge.org/core/journals/journal-of-the-history-of-economic-thought) This preprint may be used only for private research and study and is not to be distributed further.

The preprint may be cited as follows:

van 't Klooster, Jens. Marginalism and Scope in the Early Methodenstreit. Journal of the History of Economic Thought (forthcoming). Preprint at SocArXiv, osf.io/preprints/socarxiv 


\section{INTRODUCTION}

The marginal revolution is the founding moment of the economic discipline as it exists today. It was not the origin of economic science per se, but rather that of a distinct professional field focused on optimization under conditions of scarcity. This conception was made famous in Lionel Robbins account of economic as "the science which studies human behaviour as a relationship between ends and scarce means which have alternative uses." (Robbins, 1935, 16) Although it has been the object of vigorous debate ever since, the marginalist conception of the field remains influential in both research and teaching. The marginal revolution is closely associated with the Methodenstreit ("Battle of Methods"), which was a wide-ranging debate between many parties and across continents over the period between 1870 and 1914 .

The Methodenstreit was initiated by an early, highly polemical, exchange between the Gustav Schmoller and the Carl Menger in the 1870s and 1880s. Their disagreement, I will argue here, pivoted on one central question: Should economics be a narrow discipline that focuses on the optimizing behavior of individual agents? Or should it take account of the full complexity of human psychology, institutions and their historical development? Where it concerned these questions, both Menger and Schmoller did their best to engage with the views of their opponent, even if, in the end, their debate was inconclusive. This early exchange and its reception are the subject-matter of this article. By situating Menger within the battle lines of his times, I also question the widespread view of Menger as the founder of an independent "Austrian" school of economics opposed to a neoclassical mainstream.

My account of the Methodenstreit challenges three kinds of interpretation available in the literature. The first, which I refer to as methods-based, focuses on divergent philosophical background assumptions regarding the justification of theoretical claims. Some accounts still 
follow John Neville Keynes' account of it as a confrontation between inductive and deductive approaches to economics. As critics have pointed out, this interpretation does not fit the historical facts: while both sides certainly privileged their own avenue of research, Schmoller did not reject deduction from an idealized representation of economic reality and Menger empathically endorsed the legitimacy of generalizations based on collected data. The absence of substantial epistemological disagreement motivates a second strand of "skeptical" interpretations, which denies that the debate had any intellectual core to begin with. Such authors see the Methodenstreit as a "clash [] of temperaments and of intellectual bents", where both sides were "fighting [...] harmless windmills" (Schumpeter, 1954, p. 783). A third "political" account holds that the exchange was "at bottom a debate about the admissibility of social reform and other activist social policy" (Grimmer-Solem, 2003, p. 246). While these accounts certainly capture important strands of the debate that took place after 1883 , they do not accurately capture what was at stake in the initial exchanges between Menger and Schmoller.

Though there was little substantial debate on the justification of theories, there was a real topic of disagreement, namely that of the scope of the economic discipline. The scope of a scientific discipline is a prescriptive conception of what the phenomena are that a discipline should be investigating. While Menger's understanding of markets and prices was already familiar to readers, his ideas about scope were novel. For Menger, the optimizing behavior of economic agents in the allocation of scarce resources more or less exhausts the scope of economics. It is this conception of scope that I describe as marginalism in the following. Although Schmoller over the course of his career came to appreciate the importance of marginal 
analysis, he continued to reject this narrow conception of scope. ${ }^{1}$ In tracing the early debate, I show that scope was the pivotal topic around which the exchange evolved from 1871 to 1883.

Although scope has featured as one topic of disagreement in earlier accounts, ${ }^{2}$ the article makes a much stronger claim: The topic of scope is at the dialectical center of the exchange and it is in this sense really what the debate was all about. ${ }^{3}$ Both sides promote competing conceptions of scope as models for the organization of research and teaching into disciplines. Menger and Schmoller do not seek to promote a specific set of empirical propositions about the economy or methods of investigating it. Nor are they primarily concerning with political choices of how to manage the economy, although such disagreements loom in the background. ${ }^{4}$ Rather, their debate is motivated by politics internal to the academy and the role of the nascent profession of the economist. ${ }^{5}$ By establishing that Menger was preoccupied with promoting a marginalist conception of that profession, the article contributes to vindicating Menger as the first self-conscious marginal revolutionary.

\footnotetext{
${ }^{1}$ For the authors general grouped into a historical school and their position in the broader Methodenstreit see Grimmer-Solem (2003) and Cardoso \& Psalidopoulos (2015).

${ }^{2}$ Recent authors who have pointed to scope include Winch (1972), Häuser (1988), Reiss (2000) and Screpanti and Zamagni (2007, p. 189).

${ }^{3}$ In focusing on what the interlocutors seek to do, the article is follows a contextualist approach in line with Skinner (1969) and Pocock (1985).

${ }^{4}$ For accounts of Menger as pursuing a political project see Veblen (1898), Bucharin (1919), Winch (1972), Grimmer-Solem (2003) and Wasserman (2019).

${ }^{5}$ On the broader historical development of professionalization, see Lindenfeld (1998), Ross (2003) and Wallerstein (2011). For Economics, see Maloney (1991), Tribe (2007) and.
} 
I show that scope was the central topic of the early Methodenstreit by discussing (i) Menger's Principles, (ii) Schmoller's critical 1873 review, (iii) Menger's 1883 Investigations response to Schmoller's criticisms, (iv) Schmoller's 1884 review of Menger's Investigations and, finally, a short letter from Schmoller that ends the debate. My reconstruction will bring out that between the publication of Menger's Principles of Economics (1871) and Schmoller's review of his Investigations into the Method of the Social Sciences (1883), each new contribution clarifies the author's views on the scope of economic science in ways that provided substantial replies to prior criticisms issued by their opponent. In this way, a meaningful debate on scope emerges. In the Principles of Economics, Menger seeks to delimit the scope of economics to the availability of goods, given needs and choices by idealized economic agents. In a dismissive review of less than 200 words, Schmoller takes issue with the claim that it is a textbook that covers the whole of the discipline of Economics. In his second book, the Investigations into the Methods of the Social Sciences, Menger then outlines a meticulous defense of the narrow conception of the discipline implicit in the Principles. When Schmoller reviews this second book, he says little about the marginalist theory of prices or the laissezfaire economic policy that he associated with these views. Rather he claims that even accepting that the marginalist price theories are an adequate way to explain prices, it is "characteristic of an unworldly and naive armchair academic" to stop the investigation at this point and exclude many other, more fundamental factors influencing human satisfaction of needs. Instead, Schmoller argues, the discipline should explain economic phenomena as an inextricable part of social reality and, in particular, as subject to the laws of human psychology.

The narrow interpretative claim of the paper allows me to make a historiographic contribution concerning the recent development of Menger scholarship, which has prominently 
featured an anti-marginalist reading of Menger. This interpretation, however, is entirely incompatible with the positions that Menger defends in the Methodenstreit. As a consequence, the existing literature has had difficulties in pinning Menger down on a specific recognizably contemporary position precisely where scope is concerned. In the first decades of the twentieth century, this was not the case and the terms "marginalist" and "Austrian" were often used interchangeably. But, while recognizing that some statements of Menger are clearly marginalist, recent Menger scholarship puts forward a radically different reading. Consider Marc Blaug's claim that Menger

was not self-consciously aware, as Jevons and Walras were, of being a revolutionary; he eschewed mathematical formulations and hence the pure logic of extremum problems; $[\ldots]$ but, on the other hand, was deeply suspicious of all determinate theories of pricing and underlined discontinuities, uncertainties and bargaining around the market price. (1972, p. 275)

This anti-marginalist reading originates in the work of Friedrich Hayek. It situates Menger outside the marginalist mainstream; a view that is by now endorsed by a range of influential historians of economic thought. Against these authors, I point out that support for this reading is weak and, in parts, based on a misrepresentation of the available sources. Menger saw preferences as the starting point of economic explanation and the absence of mathematics in his work result, against his own best efforts, from his training as a lawyer. More importantly, it fails to recognize Menger's project as geared towards promoting a marginalist conception of scope. To the extent that the 1970s Austrian revival sought to challenge exactly that narrow understanding of economics, we should question the status assigned to Menger as an intellectual founder. There appears to be at best a modest lineage from him to today's Austrian economists.

The rest of the article is structured as follows. In section II, I distinguish the scope-based account from alternative interpretations and criticizes these. In section III, I introduce the scope- 
based account and defend it through a detailed reading of the primary texts. Section IV discusses and reject post 1970 anti-marginalists accounts and traces their origins to Friedrich Hayek.

\section{WHAT WAS THE METHODENSTREIT ABOUT?}

Although many commentators have noted that scope is one of the topics of the debate, they have failed to appreciate its pivotal status. I propose an analytic framework for studying existing interpretation of the Methodenstreit in distinguishing a methods-based, a skeptical account, a political account and a scope-based account, which I argue are all three inadequate.

\section{Methods-based accounts}

Methods-based accounts describe the Methodenstreit as a confrontation between inductive and deductive modes of theorizing. ${ }^{6}$ The origin of this reading of the debate is not in these works themselves, but in later phases of the Methodenstreit, when Menger's followers such as Eugen Böhm-Bawerk and Friedrich von Wieser ascribed to their historical school opponents a flat-out rejection of economic theorizing (Böhm-Bawerk 1890-1891; Wieser 1891). More nuanced accounts follow this focus on methods, but ascribe to both side somewhat simplistic views. Despite some disagreement on the relative importance of these different techniques of inquiry, it did not feature in any prominent way in the actual Methodenstreit. In fact, both Menger and Schmoller explicitly rejected such an interpretation of the debate.

A paradigmatic author who put forward a methods-based interpretation is John Neville Keynes. Keynes, who could not read German, based his interpretation largely on discussions

\footnotetext{
${ }^{6}$ Claims about the core of the debate along these lines can be found in Hansen (1968), Milford (1988), Steissler and Milford (1993, p. 73), Mäki (1997, p. 475f), Peukert (2001, p. 82), Caldwell (2004, p. 64f), Campagnolo (2008, p. 123f) Milonakis and Fine (2009, p. 107), and Louzek (2011, p. 455).
} 
with his mentor Alfred Marshall and translations and summaries produced by his wife (Moore, 2003). He defended his own, itself roughly marginalist, conception of the discipline by contrasting it with two extreme alternatives.

The first is "positive, abstract and deductive" (1897, p. 9), premised on the belief that "the method of specific experience is regarded as altogether inefficacious for the discovery of economic laws" (1897, p. 17). Rather, such laws should be established through deduction from “a limited number of fundamental assumptions" (1897, p. 15). Within the German economic sciences, this alternative is ascribed to the Austrians, which "insists very emphatically on the necessity of an abstract treatment of the science". Noting that Menger and his fellow Austrian economist do not actually use formal tools, he nonetheless describes them as strong proponents of "pure theory" (1897, p. 21f), stating that they were "mathematical in tone, though not in language" (1897, p. 262).

The second alternative conception of the discipline is that of historical authors, whose work is "ethical, realistic, and inductive" (1897, p. 9f) and premised on belief in "the necessity of appealing constantly to specific observation of the actual economic world, and generalizing therefrom". This conception is ethical in the sense that it denies any firm distinction between "what ought to be" and "what is" (1897, p. 23). Keynes describes Schmoller as member of a "revolutionary" wing of the historical school that denies all value in the deductive approach, going so far as to "identify political economy and economic history” (1897, p. 27).

While recognizing that the actual work of "the best economist of either school" contained elements of both, Keynes described the disputes of the time on the method of the discipline, particularly the German ones, as revolving around the opposition of deductive and 
inductive methods. As a depiction of the initial phases of the Methodenstreit, at least, this focus is flawed. For Schmoller, theorizing was an explicit and highly valued part of research. Moreover, his understanding of natural sciences clearly suggests a friendly attitude towards idealization. It is thus not surprising that, in his review of the Investigations, Schmoller is clear that he thinks that there should not be any controversy between him and Menger on this issue: "What he [Menger] says about the permissibility of isolating observed phenomena is without any doubt true; it must be admitted that such isolation has led to great progress in our science" $(1883,280)$. Nor does Menger deny the importance of finding empirical regularities based on data. It is true that in his Investigations, Menger does not hide his low esteem for the theoretical work of the historical economists. Their aims compare unfavorably to what he sees as the highest aim of theoretical economics, namely to establish an exact theory. Nonetheless, he explicitly states that he is far from "falling into the opposite one-sidedness" of "denying usefulness and significance to the realistic orientation" (1883 [1985], p. 64). Menger thus sees justification of theories through both generalization from data and idealization as legitimate.

\section{Skeptical accounts}

Skeptical accounts hold that there was no debate on any mutually recognized point of contention. The skeptical readings recognize that even if Menger and Schmoller indeed had quite divergent views on deeper philosophical issues, such topics were not explored in depth in the debate.

A paradigmatic proponent of this view is Joseph Schumpeter, who explains the debate in terms of three different properly extra-scientific causes. The first is misunderstandings between the respective parties, on account of which a "great part of the fighting is directed against [...] harmless windmills" (1954, p. 783). The second is a difference is personality. Some prefer "the colors of historical processes and of individual cultural patterns" (1954, p. 783), 
others "prefer a neat theorem to everything else" (1954, p. 783). Thirdly, scientific schools have important roles in structuring social antagonism, where concepts are used in a way to label adherence to one school or another. In fact, any attempts to find a point of substantial agreement is doomed. The reason for this, Schumpeter thinks, is that while it may be the case that Menger preferred idealization, whereas Schmoller pleaded for historical data, "there cannot be any serious question" about the permissibility and relevance of either approach. Thus, for Schumpeter, the Methodenstreit was "substantially a history of wasted energies, which could have been put to better use" (1964, p. 782).

More recent work on the early Methodenstreit does not always fit neatly into these two camps. Some authors combine elements from both the method-based and skeptical interpretation in arguing that though Menger and Schmoller did disagree over methods, the differences were in fact so minute as to not warrant much fuzz. Hansen and Backhaus (2000) and Tribe (2007, 66f), for example, claim that the Methodenstreit revolves around differences in emphasis, exacerbated by misunderstandings of each side's positions. Tribe (2007), for example, shows that Menger and Schmoller disagree over their preferred way of doing research: Menger aimed to formulate the propositions of economics in their highest possible degree of idealization, while Schmoller thought that collecting more data was crucial to making scientific progress. But this was never what the debate was about. In fact, both sides repeatedly sought to steer the debate away from these issues, which they saw as tangential to the core of their disagreement.

\section{Political accounts}

Recent research on the societal and scientific project of the historical authors has complemented the skeptical account with a better understanding of the political views of Menger and Schmoller (Peukert, 2001). In this literature, Eric Grimmer-Solem (2003) shows that Schmoller 
and the wider Verein für Sozialpolitik emphasized the practical use of science for public policy and were active proponents of the social reform movement. In this, they were far removed from Menger, who adhered to "a policy of uncompromising laissez-faire in which the state had fewer public duties than in Smith's Wealth of Nations" (Grimmer-Solem 2003, p. 252). Moreover, Grimmer-Solem shows, both parties actively used their academic and administrative positions to frustrate the careers of their opponents.

Although his account has the merit of contextualizing the debate, it overstates this case in claiming that the Methodenstreit was "at bottom a debate about the admissibility of social reform and other activist social policy" (Grimmer-Solem, 2003, p. 246). The same goes for Robbin's (1932, p. 82) claim that the motivation of the historical economist was "political in nature" coming from "men with an axe to grind $[\ldots .$.$] wishing to pursue courses which the$ acknowledgement of law in the economic sphere would have suggested to be unwise".

First, the fact that there was a political dimension to the Methodenstreit does not prove the absence of disagreement regarding scientific method. Political disagreement can motivate specific methodological positions even though their justification is formulated in terms of scientific considerations. Alternatively, political and methodological disagreement can exist alongside each other. Second, if the debate was indeed at its core political, then why did no substantial engagement over political issues enter into it? One would expect the political dimension of the debate to surface at least somewhere in the exchange between its protagonists, but in the whole of this exchange Menger only refers briefly to the political views of his opponent (1883 [1985], pp. 91-2). To find a proper topic of disagreement, we need to focus on the texts of the debate itself, which I now turn to. 


\section{A DEBATE ABOUT SCOPE}

Menger and Schmoller debated (and recognized that they debated) this specific question: What should be the scope of the discipline of economics? I will show that scope was the central topic of the Methodenstreit, by following the succession of arguments put forward by Menger and Schmoller and documenting how their positions change in response to moves made by their interlocutor.

\section{The importance of scope}

The scope of a scientific discipline is a prescriptive conception of (i) the explananda and (ii) the explanantia that are specific to an individual scientific discipline. A theory explains events by subsuming them or taking them to instantiate more general regularities. Within such theories, some phenomena or occurrences serve as explananda. The theory explains their occurrence. A typical explanandum of economic science is the price of a good. Such an explanandum is explained in terms of other phenomena or occurrences: the explanantia. For marginalists, the central explanans of economics is human need, but this is only one of the many phenomena that may be taken to stand in a causal relation to prices. Briefly stated, the disagreement of Menger and Schmoller on scope can be characterized as follows: where Menger though that only certain explanantia, those typical of marginalism, should be used in economic science, Schmoller thought that such a restriction on the scope of the discipline was a mistake.

The view that the real debate was about scope is not just my own. It can readily be discerned from different statements by both Menger and Schmoller that will be discussed in the following. The most explicit claim to this effect is made by Menger, who more than 20 years after the publication of his Principles wrote:

The conflict that arose between the Austrian School and part of the historical economists in Germany was not one on method in the usual sense of the word. Though historical German 
economists are - also in scientific works - often referred to as representatives of an inductive and the Austrian economists as representing a deductive approach, this does not reflect the facts about the relative positions. What grounds the differences between the two schools, which have not been completely solved to this day, is something much more important: it concerns different opinions regarding the goals of research, the system of problems that the science of the economy should solve (1894, p. 279)

In spelling out what he takes to be the crucial topic of debate, Menger seeks to correct authors who have focused on the issue of deduction and induction by pointing to the importance of scope. This claim is not a later interpretation on the part of Menger: he already used a very similar formulation in the Preface of his Investigations (1883 [1985], p. 25f).

Understanding the Methodenstreit as a debate about scope strikes a middle ground between an internalistic focus on methodological positions and externalistic sociological explanations. While the Methodenstreit was more than a clash of characters or world views, the actual debate was directly linked to and informed by the political views of both Menger and Schmoller. It takes place against the background of the professionalization of the social sciences (Lindenfeld, 1998; Ross, 2003). Then, as now, choices regarding the subject-matter of individual disciplines in research and teaching had clear political dimensions. For a laissez-faire liberal such as Menger, it made sense to focus on contract-based exchange on markets and price mechanisms as the means for an efficient allocation of goods. By contrast, Schmoller was in favour of pro-active social reforms, which makes requires reforming a wider set of legal and social conditions for the satisfaction of needs. In fact, Menger directly ties scope to politics in the Investigations, where he writes of the desirability of a conception of scientific method that would defend "existing economic schools and interests against the exaggerations of reform thought in the field of economy, [...] especially against socialism" (1883 [1985], p. 92f). Menger thus makes some effort to connect his own position to his rejection of political views 
he ascribes to opponents, who he accuses of socialist sympathies. But, as I show, policy issues do not come up in the debate, nor is politics at the center of the exchange. Instead, it revolves around scope.

\section{Menger's revolution}

In the Preface of his Principles, Menger denounces "the sterility of all past endeavors" (1950 [1871], p. 46). It is in the context of his new start that Menger claims that his work covers "the most general teachings of our science" and constitutes a "reform of the most important principles of our science" (1950 [1871], 47).

How exactly the proposed reform should be understood is not immediately apparent. Menger dedicates the Principles to Wilhelm Roscher, who had introduced the very idea of a historical approach that Menger would criticize vehemently in later works. Menger also goes to great lengths in his footnotes to present his work as continuous with the existing tradition in economics. Rather than trumpeting differences, Menger is keen to stress continuity. The conciliatory tone of the Principles may explain in part why not all contemporaries recognized the reform that Menger aimed to bring about, and why a reading of the Principles as a founding document of marginalism is to this day controversial. ${ }^{7}$

What is clear from the preface, however, is that Menger thought that his Principles were roughly coextensive with the proper scope of the discipline. One way in which that claim is supported is by the very concept of economic that it relies on. Menger writes that the economic character of goods is determined solely by the "difference, capable of exact determination, in the relationship between demand for and available quantities of these goods" (1950 [1871], p.

\footnotetext{
${ }^{7}$ For the failed reception of Menger by Roscher see Hansen (1968, p. 161).
} 
101, translation modified). The actions of economic agents [wirtschaftende Subjekte] are similarly covered entirely by the Principles. For Menger, economic agents seek to approximate the point where no further exchange can improve satisfaction of their needs (i.e. where all available goods have the same marginal utility). Actual choices can be found at "a limit [Grenze] at which the full economic gains to be obtained from the exploitation of a given ratio are reached, and beyond which any exchange of further portions begins to become uneconomic." (1950 [1871], p. 182). In this way, his theory explains economic actions in terms of choices by economic agents regarding available goods and given needs. This fulfils the stated aim of the Principles, as they are articulated in the Preface, namely that of "placing all price phenomena [...] under one unified point of view" (1950 [1871], p. 49).

For Menger, the actions of economic agents can be explained while taking needs and available goods as given. Conditional on the claim that such a theory indeed convers the entire "field of economics" (1950 [1871], p. 49), Menger successfully delimited the proper explanantia of theoretical economics to the availability of goods, given needs and choices by idealized economic agents.

\section{Schmoller's Challenge}

While Menger's 1871 Principles are today generally read as a contribution to economic science, what interested Schmoller most in his review was its stated aim of reforming the economic discipline. He responded with a short, critical review, which touches on scope in two ways. First, Schmoller suggested that the highly abstract nature of the Principles makes it practically irrelevant: "The results are the indubitable product of a not ordinary acumen [Scharfsinn]; but they amount to no more than new formulations of abstract conventional topics rather than actual solutions to real problems." (2003 [1873], p. 407). 
Second, Schmoller says that the Principles mistakenly claim to cover the whole range of questions that belong to the discipline:

It consists of ingenious [scharfsinnig] analyses of some of the basic concepts of economics. For a text book that would claim to be current, the entire direction of the study is already too one-sided. And perhaps the author would have done better not to have presented his studies to the public in textbook form" (2003 [1873], p. 408)

Schmoller's repeated talk of "acumen" [Scharfsinn] suggests a certain admiration for Menger's overall scientific theorizing. At the same time, Schmoller clearly aware that the stated aim of reform and the format of a text book imply a conception of the discipline at odds with his own. At the very least, Schmoller does not seem particularly impressed by this aspect of Menger's work. The historical economist Bruno Hildenbrandt echoes this verdict in his review of the Principles when he writes that "it would be in the interest of our science if its younger and aspiring researchers [Kräfte] would focus on writing monographs rather than splintering their force [Kraft] in textbooks." (Anon. 1872, 345; cf Grimmer-Solem, p. 251).

\section{Menger's reply}

Menger was infuriated by the generally cold reception of his Principles (Grimmer-Solem 2003, p. 246f). Nonetheless, it appears to have made him acutely aware of the fact that the Principles provide no explicit account, let alone defense, of his reform of economics. This lacuna is addressed head-on in Menger's Investigations of 1883, which puts forward a detailed defense of the conception of scope that demarcated the subject-matter of his 1871 textbook. Prefiguring the formulations of Menger's 1894 claim (cited at the start of this section) that the Methodenstreit was a debate on scope, the Preface of the Investigations state that the work:

is primarily concerned with determining the nature of political economy, of its subdivisions, of its truths, in brief, with the goals of research in the field of our science. Methodology in the 
narrower sense of the word is chiefly to be reserved for future investigations (1883 [1985], p.

Before stating the concern of the Investigations with the aims of science, Menger discusses why this topic is particularly timely. Menger's complains extensively about the hostility of his contemporaries towards theory. However, this is not his only worry. Historicists have also proposed that the "phenomena of national economy are to be treated in inseparable connection with the total social and political development of nations" (1883 [1985], p. 25). Worse, they have even denied that "political economy in general is to be dealt with as an independent science" and instead understood it "as an organic part of a universal social science" (1883 [1985], p. 25).

By arguing against these opponents, Menger is able to address both challenges raised by Schmoller. Against the objection of practical irrelevance, Menger responds by distinguishing theoretical from practical science. Just like historical sciences, practical economic science also considers particular phenomena, but with the aim of addressing policy problems. This means that the practical sciences should not aim to develop knowledge of what is the case, but only of means to bring about given ends (1883 [1985], p. 38). Though a practical science involves factual statements, Menger thinks that its research should be guided by practical rather than epistemic aims. As the theoretical sciences do not have such practical aims, Menger goes far in conceding Schmolller's first criticism: though it may be used for such purposes by other disciplines, theoretical economics does not have direct practical relevance.

The distinction between practical and theoretical sciences also plays a crucial role in the answer to Schmoller's second criticism. Because the aims of theoretical sciences are purely epistemic, they are not to be judged by their real-world application. For Menger, the aim of 
theoretical science is knowledge of types and their explanatory relations independent of specific historical conditions. Invoking his ideal of exact theory, Menger argues that the regularities described by the historical economists will never hold without exception and are therefore of lesser scientific value. They only provide: "results which are formally imperfect, however important and valuable they may be for human knowledge and practical life" (1883 [1985], p. 59). To be able to develop a pure theory, theoretical disciplines need to focus on one particular aspect of social reality. According to Menger, a division of labor between the sciences is the only way to find exact theories that together describe reality as a whole (1883 [1985], p. 62f).

The claim that there need to be distinct exact theories does not fully justify Menger's specific conception of scope. It could still be the case that there need not be a distinct field of theoretical exploration of the economy to begin with, but rather one large field of theoretical social inquiry. Menger's true innovation at this point is to delimit the explanantia of the discipline in an entirely new way. As a pioneer of methodological individualism, Menger argues that social theory should take the decisions of individuals as final explanantia. The task of the theoretical economist is to explain human action by describing the "most elementary factors in human economy, in their isolation from other factors exerting influence on the real human phenomena." (1883 [1985]) To do this, as Menger had already demonstrated in his Principles, the economist need only focus on given needs and available goods, while assuming that agents satisfy their needs as efficient as possible:

\footnotetext{
The most original factors of human economy are the needs, the goods offered directly to humans by nature (both the consumption goods and the means of production concerned), and the desire for the most complete satisfaction of needs possible (for the most complete covering of material needs possible). (1883 [1985], p. 63)
} 
In these passages, Menger proposes in rough outline the marginalist conception of discipline that Robbins would later canonize, explicitly citing the Investigations as its origin (Robbins, 1935, p. 16). That conception is not new in its conception of the explananda of economics, which by the middle of the $19^{\text {th }}$ century were broadly thought to be exchange, consumption, and production (Tribe 2007, p. 66f). Menger's view is that the field of economic science is not just demarcated by a specific set of explananda to economic science, but also by a specific set of explanantia. But, if that is so, then the Principles do actually cover the entire scope of theoretical economics. In a footnote, Menger makes this claim in citing his Principles, otherwise not regularly invoked in the Investigations, as a text that applies the exact method to the domain of economic phenomena (1883 [1985], p. 63n). For Menger, such a theory does not merely present one possible social theory of economic phenomena amongst others. Rather, they are an exemplary contribution to properly economic research. ${ }^{8}$

\section{Schmoller's rejoinder}

Before outlining how Schmoller responded to the Investigations, it is important to discuss the points of agreement that Schmoller emphasizes in his second, 1884 review. In this review, Schmoller put considerable effort into downplaying the extent to which he and Menger disagreed. He explicitly accepts Menger's views on three important points with the aim of clarifying that their true disagreement concerns scope.

First, Schmoller stressed that their agreement on the proper explananda of economics, which was common to $19^{\text {th }}$ century German economists, when he states that "our science" should only provide "a theory of the economic side of society" (1883, p. 282). In using the term

\footnotetext{
${ }^{8}$ This is an important caveat to Dekker (2016)'s claim that Menger “feels part of a broader group of social scientists and historians." (p. 4f)
} 
economic for the study of the satisfaction of need, Menger and Schmoller agreed that human satisfaction of needs was the proper explanandum of economics.

Second, Schmoller stressed his agreement with Menger on the scientific value of finding universal regularities. As critics of a methods-based account of Methodenstreit have highlighted, Schmoller never denied the importance of theorizing. More generally, his responses to the arguments of Menger on this issue concede a great deal of ground. Thus, regarding the difference between the naïve empiricism that Menger criticized and the exact method, Schmoller writes that it is "without doubt justified to a certain extent" (1883, p. 278). Equally, Schmoller emphasizes that the value of theoretical work in economics should not be underestimated and that "the historical movement may have exaggerated its precautions against generalizations and theories" (1883, p. 279). Schmoller certainly does not deny that Menger's price theory offers important insights. Indeed, despite Schmoller's earlier dismissal of the Principles, he was more than happy to incorporate marginal analysis into his later lectures (Tribe, 2007, p. 79).

Third, Schmoller agrees that research on social reality should be pursued by separate disciplines that have specific aspects of social reality as their remit. Already in his 1867 review of the work of Lorenz von Stein, Schmoller stated that his wide-ranging discussions were antiquated (Siclovan, p. 255). Instead, scientific progress Schmoller held that careful empirical investigations of different parts of social reality. On the basis of such studies, individual social theories should be developed to prepare for "a new epoch" where a theoretical understanding of society as a whole would be available (1883, p. 279). Thus, any arguments by Menger that invoked the need for a scientific division of labor were welcomed by Schmoller, who also 
accepts the need for small steps in the development of science: "only through one-sidedness can we mortals achieve anything" (1883, p. 279).

If Schmoller agrees with Menger on all of this, where does he see the real point of disagreement? Schmoller's most forceful critique in his 1883 review of the Investigations focuses on Menger's narrow conception of explanantia. In stark contrast to his conciliatory tone on other issues, Schmoller does not mince words when it comes to the scope of economics: "it is - in my subjective impression - characteristic of an unworldly and naive armchair academic to see human needs or the desire for acquisition or self-interest as final, most basic elements in the scientific sense of the word" (1883, p. 281f).

Though Schmoller clearly does not believe that needs are the most fundamental explanantia for a theory of economic action, he recognizes that there are no scientific reasons to reject such a theory. Rather, Schmoller focuses his critique on the very aim of demarcating individual sciences in terms of a narrow set of explanantia:

\footnotetext{
What he [Menger] says about the permissibility of isolating observed phenomena is without any doubt true; it must be admitted that such isolation has led to great progress in our science. It is, however, quite crooked to see an irreconcilable contradiction between isolation and the universal consideration of all relevant causes. [...] No sane man will demand that an isolation that is successfully applied once should be binding for all further investigations in the same scientific discipline. (1883, p. 280)
}

By pointing to the legitimacy of pursuing different scientific interests, Schmoller seeks to stress that subjective theories of value may very well have a place in the economics discipline but cannot be taken to define it. He therefore concludes that Menger has mistaken "a small corner of the big building of our discipline, that only he knows best and in which he has nested 
himself with acumen [Scharfsinn] and erudition, for the whole building." (1883, p. 293f).

\section{The aftermath}

After Schmoller's second review, the substantial exchange between Menger and Schmoller ends. In his Errors of Historicism (1884), Menger merely iterates his earlier arguments in a much more polemical tone. Even Hayek, who talks of the book's "extraordinary power and brilliance of expression", admits that it "adds little in substance to the Untersuchungen" (1934, p. xxii). Schmoller decided not to review it, but rather printed a short letter in his Jahrbuch asking Menger to refrain from further escalation of the debate.

\section{Menger the marginal revolutionary}

My reconstruction of the Methodenstreit serves to cast Menger as a proponent of a marginalist conception of the discipline. It is very much like that commonly associated with Lionel Robbin and hence a key moment in the history of modern economic science. Understanding Menger's preoccupation with scope provides an important background to his work on other topics. His views on the predominance of spontaneous organization, his theory of choice, and his treatments of specific economic phenomena such as goods, prices and production can be seen as tactical moves in a duel whose stakes were a radically new understanding of the discipline. Menger's treatment of money constitutes a case in point. ${ }^{9}$ Explaining the origins of money solely through his limited set of explanantia validates Menger's marginalist conception of scope. Indeed, these stakes were clear to both Menger and his contemporaries. Opposing the marginalist landgrab, the German economist Georg Gustav Knapp's explicitly identifies the assimilation of money to political science as the main aim of his The State Theory of Money (1924 [1905]; cf. Semenova, 2014, p. 126f). The debate on scope also explains the relative

\footnotetext{
${ }^{9}$ This topic was recently debated by Ikeda (2008) and Semenova (2014).
} 
facility with which Menger could accommodate a secondary role for the state: he does not have any grounds to deny that social reality in its totality is complex and involves opaque causal interrelations. For Menger it is primarily important that the economist can provide an exact theory of this paradigmatically economic phenomenon. This Menger could do, even while accepting that the state played a role in later stages of monetary development.

\section{RECENT ANTI-MARGINALIST INTERPRETATIONS}

Section III shows the important role of the marginalist conception of scope in both Menger's Principles and the Investigations. This claim stands in striking contract with the more recent interpretation of his work, which situate him outside the marginalist mainstream. The origins of this view of Menger as an opponent of the marginalist conception of scope can be found in the work of Friedrich Hayek.

In the early decades of the twentieth century, Menger was universally perceived to be a proponent of marginalism. This view was not only emphatically defended by Austrian followers, ${ }^{10}$ but also routinely invoked by opponents,,${ }^{11}$ and more or less neutral outsiders, ${ }^{12}$ who all used the terms "marginalist" and "Austrian" interchangeably. On this traditional view, Menger is often portrayed as a less sophisticated version of Stanley Jevons and Léon Walras, who relies on words rather than mathematical formalism (e.g. Knight, 1950). But what Menger

\footnotetext{
${ }^{10}$ E.g., Boehm-Bawerk (1890, p. 265), Wieser (1891, p. 108), Mises, (1969, p. 1). It may also have been Hayek's considered view, see Hayek (1972).

${ }^{11}$ E.g., Veblen (1898, p. 389) and Bucharin (1919, p. 33)

${ }^{12}$ E.g., Keynes (1897, p. 262) and Wicksell (1934, p. 28). Schumpeter sees Menger as a marginalist theorist of value but denies any novelty with regard to the scope of the discipline of economics, which he considers identical to that of Smith and Mill (1954, p. 859).
} 
lacked in technical sophistication, he made up in reflection on the presuppositions of marginal analysis. As touched on earlier, Robbins repeatedly insisted that his definition of the discipline should be traced to Menger, not himself. In a 1938 contribution to the debate on his Essay, Robbins writes:

\begin{abstract}
In recent years, following Menger, some of us have canvassed the claims of definitions which explicitly draw attention to that fundamental limitation of goods in relation to wants which is the condition of the existence of conduct having an economic aspect. Economics, we have suggested, is essentially the study of the disposal of scarce goods and services. (1938, p. 344)
\end{abstract}

Robbins is surely aware that Menger talks about phenomena such as error, uncertainty, technology and the complexities of human psychology. But from his view, which I take to be largely correct, such topic do not occur as the subject-matter of the economic discipline. Rather, Menger discusses them to explain what an exact economic theory ought to abstract from. That this is his main interest is very clear from the Investigations, but less so when reading the Principles in isolation. The distinction between explanantia in a theory and abstracta of a theory is subtle, but when confused, this can lead to a crucial mistake concerning Menger's views on scope.

The positions that are ascribed to Menger in my reconstruction of the Methodenstreit provide decisive support for the traditional view: Menger was a defender of the marginalist conception of scope, and therefore a marginalist if the term has any meaning. As a consequence, my reconstruction is squarely at odds with some views expressed in more recent Menger scholarship. In fact, around time of the 1970s "revival" of Austrian economics, a very different reading of Menger emerged. 
The decisive text in understanding this turn is Hayek's English-language introduction to the 1934 Collected Works of Carl Menger, which is itself in German. As the introductory text to the most widely available German language edition of his works it served as a portal into Menger's idiosyncratic prose. The 1950s English translation, despite Hayek's active involvement in its creation, contains a critical introduction by Frank Knight that fits well with the traditional marginalist interpretation. ${ }^{13}$ This introduction, however, is quietly dropped from the 1976 re-edition by the Institute for Humane Studies in favor of Hayek's. Around that time it becomes a key reference point for the interpretation of Menger. A new reading of Menger becomes so central to the 1970 s Austrian revival that economists come to think of their antimarginalist views "continuation of a research program begun by Carl Menger in 1870 but truncated in the early part of the twentieth century as the economics profession became more and more entranced first with Marshall and then with Walras" (Vaughn 1990, p. 379; cf Kirzner 1992).

Hayek finds in the Principles a developed account of production and an extended meditation on the problems of economic planning, prefiguring his own position in the Socialist Calculation Debate. According to Hayek, Menger sees economic activity as "essentially planning for the future" (1934, p. xiii), subject to strong uncertainty and error. He thereby

\footnotetext{
${ }^{13}$ As Knight puts it, "If Menger was aware of the many other "men" who walk about and variously perform "in the same skin" as the creature who merely uses "means" to satisfy "needs" (the automatic mechanism, the conventional man, the playful, humorous, contentious, prejudiced, capricious, perverse, obdurate, destructive, benevolent man, the idealist, the esthete, the malicous man, etc, etc) his Grundsätze gives no evidence of this fact.”(1950, p.
} 
portrays Menger as theorist of the psychological and institutional phenomena that are ignored in theorizing marginalism's maximizing agent. Hayek also suggests that Menger was "sceptical" about the use of mathematics in economics $(1934$, p. i). Instead of a marginal revolutionary, Menger suddenly appears as a committed proponent of a pluralist conception of scope.

Hayek's interpretation has proven of immense influence over Menger scholarship. Consider Marc Blaug's claim already cited in the introduction. William Jaffé (1976), similarly, questions the usefulness of the very term "marginal revolution" in understanding Menger's role in the history of economic thought. Erich Streissler, stressing the continuity of his interpretation with that of Hayek, positively denies that Menger was a marginalist. To this aim, he cites the Principles as follows: “to put it in Menger's own words, it was 'not merely [!] his endeavor to create a unified theory of price."' (1972, p. 426- 427). But, in contrast to what Streissler's referencing leads the reader to believe, the 1950s translation by James Dingwall and Bert Hoselitz does not contain the quoted passage (see Menger 1950 [1871], p. 49), nor does the original German leave room for a translation along the lines that Streissler proposes. By suggesting that marginal analysis is only tangential to Menger's economics, these authors move beyond Hayek. Hayek points to what he sees as neglected non-marginalist aspects of Menger, while at the same time he is clear that these are meant to 'prepare the way for that main task' namely "as he [Menger] says in the Preface [...] a uniform theory of price" (1934, p. xii). 
Nonetheless, Hayek introduced a tradition of interpretation that persists to this day in denying that the main topic of the Principles is a marginalist explanation of prices. ${ }^{14}$

One influential claim that Hayek (1934) introduces and is regularly echoed by more recent authors concerns Menger's views on mathematics. ${ }^{15}$ Jaffé, citing Hayek's introduction, claims that "Menger avoided the use of mathematics in his economics not because he did not know any better, but out of principle" $(1976,521)$. As Jaffé and those drawing on him argue, the absence of formalism in Menger's work must betray a methodological choice. This is a dubious inference. The mere absence seems to be adequately explained by Menger's education at the Law faculty in Austria, as a consequence of which he and his fellow Austrians did not share the natural sciences background of Jevons, Walras, and, in fact, Schmoller. Menger's son, the mathematician Karl Menger, provides the following directly relevant biographical evidence:

in the 1890 s my father indeed started such a self-study, as is clear from a three-page introduction into the elements of differential calculus in his handwriting, which he had bound into his copy of the second edition of Walras's Elements d'economie politique pure. But I am afraid that he did not acquire an operative knowledge, let alone a critical insight into calculus $(1973,44 \mathrm{f})$

\footnotetext{
${ }^{14}$ More recent authors who see marginal analysis as tangential to Menger's economics include Peart (1998), Gloria-Palermo (1999, 11), Caldwell (2004, 17f) and Campagnolo (2010, 302f).

${ }^{15}$ Recent authors who ascribe a principled objection to mathematics to Menger are Streissler (1972, p. 440), Blaug (1973, p. 275), Mirowski (1989, p. 259f), Gloria-Palermo (1999, p. 2), Caldwell (2004, p. 31) and Campagnolo (2010, p. 303f).
} 
There are also good non-biographical reasons that speak against Hayek's claim. In spelling out his exact method, Menger is clear that he is not merely interested in finding a qualitative account of causal relations, but also explicitly in doing so in a quantifiable way. The term that Menger uses for such a quantifiable relation is the 'measure' (das Maß) of an exact relation (1985 [1883], 60). Menger saw his exact method as a precondition for the application of mathematics (Reiss, 2000). This, again, speaks against any principled objections to its use in economic science.

One place where Menger makes the claim that the exact method is a presupposition of the application of mathematics is in his letters to Walras (1965 [1884]). These letters are sometimes cited to situate Menger outside the marginalist mainstream. In particular, authors have misrepresented a passage where Menger here distances himself from his contemporary Hermann Gossen (1810-1858), who proposes a version of marginal analysis a few years earlier:

\begin{abstract}
I would be otherwise be happy to send you my 'Principles 1871 ', so that you could compare my work with that of Gossen. There is, as I have determined, agreement between us, or rather likeness in opinion, in some respects but not on the decisive questions. I will make this clear in the next edition of my Principles and give due recognition to the achievements of Gossen.
\end{abstract} $(1965$ [1887])

Kauder (1956, p. 100) and more recent authors cite the second sentence from this passage in isolation to create the impression that Menger rebukes Walras. ${ }^{16}$ Not only is this a misleading way of representing this passage, it also goes against the wider spirit of the exchange. After outlining his view on the relation between economics and mathematics, Menger had already

\footnotetext{
${ }^{16}$ See Gloria-Palermo (1999, p. 20), Campagnolo (2008, p. 84; cf. 2010, 310; p. 371), Infantino, (2010, p. 169), and Wagner, (2010, p. 183). On this, Streissler (1972, p. 439).
} 
concluded: "I know, my esteemed colleague, that you will find nothing new in my explanations! I know that you and I are in full agreement on this point" (1965 [1884]).

\footnotetext{
A final claim made by Hayek is that to Menger, the world was a subject for study much more than for action, and it was for this reason only that he had intensely enjoyed watching it at close range. In his written work one can search in vain for any expressions of his political views. (1934, xxxv)
}

This claim is reflected in existing Menger scholarship, which has treated his work primarily as that of an economic theorist. Hayek's claim, however, is in accurate. As I already showed, Menger did have his own political views. In the Investigations, in fact, Mengers contrast Schmoller unfavourably with Savigny's Historical School of jurisprudence, which Menger portrays as welcome counter revolutionary force against the French Revolution's "failure to recognize the nature of law, state, and society and their 'organic origin' (1883 [1985], p. 91) that supported "conservative basic principles highly useful to the ruling interests" (1883 [1985], p. 91). The German historical authors, he laments, support more interventionist policies and "no small part of them most recently offered the rare spectacle of a historical school of economists with socialistic tendencies" (1883 [1985], p. 91). Menger, if not a political activist, was keen to shape the scientific discipline in a direction that fit well with his own views. There is considerable agreement that little, if anything, in his marginalism was original (Ekelund \& Hébert 2002). However, the shape that the marginalists gave to economics, the questions that they took to fall within its remit and those that stayed out, are, for better or, probably worse, with us to this day. It is simply naive to omit such aspects of the theorizing of an economist whose political effects have been so profound. That, however, is not just my view, it is also that of Hayek, who himself wrote only one year before publishing his preface on Menger that 
economic analysis has never been the product of detached intellectual curiosity about the why of social phenomena, but of an intense urge to reconstruct a world which gives rise to profound dissatisfaction (1933, p. 122)

\section{CONCLUSION}

The foregoing discussion shows that the initial phases of the Methodenstreit revolved around a substantial and mutually recognized point of contention. Where Menger thought that only certain explanantia should be used in economic science, Schmoller rejected such a restriction of the scope of the discipline. Importantly, the position of both parties developed during the debate. The Principles do not yet explicitly address the professional ethos of the economist. This claim is only formulated in the Investigations. In the Principles, Menger does not discuss economic phenomena to establish a conception of proper subject-matter, but as elements within a specific theory of social reality. In this sense, Menger's arguments in the Investigation can be understood as replying in a cogent way to Schmoller's 1874 review. Schmoller's 1883 review then serves to push home the point that, though Menger has provided reasons for his claim, Schmoller is not convinced. In doing so, he explicitly rejects one premise in Menger's argument, while at the same time stressing agreement on many other issues not pertinent to proper scope. Hence, large parts of the later debate may indeed have been a "substantially a history of wasted energies" (1954, p. 782), but at least, as I hope to have shown, rather than a knight fighting a windmill, as Schumpeter has it, the initial phases featured two discussants engaged in a messy but argumentative joust. Recent Menger scholarship has failed to appreciate that following Hayek's suggestive, but fundamentally flawed, interpretation of Menger as an opponent of marginalism. 


\section{REFERENCES}

Anon. (1872). "Drei neue Handbücher der Volkswirtschaftlehre", Jahrbücher für Nationalökonomie und Statistik, 18: 342 - 345.

Backhaus, J. and Hansen, R. (2000). "Methodenstreit in der Nationalökonomie", Journal for General Philosophy of Science, 31: 307-336.

Blaug, M. (1972) “Was there a marginal revolution?” History of Political Economy, 4 (2): 269 $-280$.

Böhm-Bawerk. E. (1890-1891). The Historical vs. Deductive Method in Political Economy, Annals of the American Academy, 1: 244 - 271.

Bukharin, N. (1919/1972). Economic Theory of the Leisure Class. New York/London: Monthly Review Press.

Caldwell, B. (2004). Hayek's Challenge. Chicago: University of Chicago Press.

Campagnolo, G. (2008). Carl Menger: Entre Aristote et Hayek. Paris: CNRS Édition.

Campagnolo, G. (2010). Criticisms of Classical Political Economy: Menger, Austrian Economics and the German Historical School. London and New York: Routledge.

Cardoso, J. L. and Psalidopoulos, M. (2015). The German Historical School and European Economic Thought. Abingdon: Routledge. 
Dekker. E. (2016). The Viennese Students of Civilisation. Cambridge: Cambridge University Press.

Ekelund Jr, R. B., \& Hébert, R. F. (2002). Retrospectives: The Origins of Neoclassical Microeconomics. Journal of Economic Perspectives, 16, 197-215.

Grimmer-Solem, E. (2003). The Rise of Historical Economics and Social Reform in Germany, 1864-1894. Oxford: Clarendon Press.

Hansen, R. (1968). "Der Methodenstreit in den Sozialwissenschaften zwischen Gustav Schmoller und Carl Menger. Seine wissenschaftshistorische und wissenschaftstheoretische Bedeutung" (137- 173), In: Diemer, A. (eds.) Beiträge zur Entwicklung der Wissenschaftstheorie im 19. Jahrhundert. Meisenheim am Glan: Anton Hain.

Hayek, F. (1933) “The trend of economic thinking”, Economica 40: 121-137.

Hayek, F. (1934). "Carl Menger (1840-1921)” In F.A. Hayek (Ed.), The Collected Works of Carl Menger. Vol. I. 1934. London: The London School of Economics and Political Science,

Hayek, F. (1972). "Die Stellung von Mengers "Principles" in der Geschichte der Volkswirtschaftslehre”, Zeitschrift für Nationalökonomie, 32: 3 - 9.

Häuser, K. (1988). Historical School and Methodenstreit. Journal of Institutional and Theoretical Economics 144:532-42. 
Ikeda, Y. (2008). Carl Menger's monetary theory: A revisionist view. European Journal of the History of Economic Thought, 15 (3): 455-473.

Infantino, L. (2010). 'Hayek and the Evolutionary Tradition Against Homo Oeconomicus' Advances in Austrian Economics, 13: 159-177.

Jaffé, W. (1976) "Menger, Jevons and Walras De-Homogenised", Economic Inquiry, 14 (1): $511-24$.

Kauder, E. (1956). A History of Marginal Utility Theory. Princeton: Princeton University Press. Keynes, J. N. (1897). The Scope and Method of Political Economy. London: Macmillan and Co.

Kirzner, I. M. (1992). The Meaning of the Market Process. London: Routledge.

Knapp, G.F. (1924 [1905]). The State Theory of Money. (H.M. Lucas and J. Bonar Trans.).

London: Macmillan and Co., Ltd

Knight, F.A. (1950) “Introduction” In: Menger, C. Principles of Economics. (J. Dingwall and B. Hoselitz, Trans.). New York: The Free Press.

Louzek, M. (2011). "The Battle of Methods in Economics. The Classical MethodenstreitMenger vs. Schmoller: The Battle of Methods in Economics." American Journal of Economics and Sociology, 70(2), 439-463.

Lindenfeld, D. (1999) The Practical Imagination. Chicago: University of Chicago Press. 
Maloney, J. (1991). The Professionalization of Economics: Alfred Marshall and the Dominance of Orthodoxy. London: Routledge.

Mäki, U. (1998). 'Universals and the Methodenstreit: a Re-examination of Carl Menger's Conception of Economics as an Exact Science", Studies in History and Philosophy of Science Part A, 28 (3): 475-495

Milford, K. (1989). Zu den Lösungsversuchen des Induktionsproblems und Abgrenzungsproblems bei Carl Menger. Vienna: Verlag der Österreichische Akadademie der Wissenschaften.

Milonakis, D., and Fine, B. (2009). From political economy to economics: method, the social and the historical in the evolution of economic theory. London; New York: Routledge.

Menger, C. (1950 [1871]). Principles of Economics. (J. Dingwall and B. Hoselitz, Trans.). New York: The Free Press.

Menger, C. (1883 [1985]). Investigations into the method of the social sciences, with special reference to economics. New York: New York University Press.

Menger, C. (1965 [1884]) Menger to Walras, February 1884. In: Jaffé, W. (1965) The Correspondence of Walras and Related Papers, vol. II 1884 - 1897. Amsterdam: North Holland Publishing Company. 
Menger, C. (1887) “Zur Kritik der Politischen Oekonomie”. In: Menger In F.A. Hayek (Ed.), The Collected Works of Carl Menger. Vol. III. 1935. London: The London School of Economics and Political Science.

Menger, C. (1965 [1887]) Menger to Walras, 27 January 1887 In: Jaffé, W. (1965) The Correspondence of Walras and Related Papers, vol. II 1884 - 1897. Amsterdam: North Holland Publishing Company.

Menger, C. (1887) Zur Kritik der Politischen Oekonomie In: Menger In F.A. Hayek (Ed.), The Collected Works of Carl Menger. Vol. III. 1935. London: The London School of Economics and Political Science.

Menger, C. (1894) "Wilhelm Roscher”. In: Menger In F.A. Hayek (Ed.), The Collected Works of Carl Menger. Vol. III. 1935. London: The London School of Economics and Political Science.

Moore, G.C. (2003). "John Neville Keynes and the English Methodenstreit". Journal of the History of Economic Thought. 25 (1): 5-38.

Peart, S.J. (1998). “Jevons and Menger Re-Homogenized?: Jaffé after 20 Years”. American Journal of Economics and Sociology 57, 307-325.

Peukert, H. (2001). “The Schmoller Renaissance”, History of Political Economy, 33 (1): 71 116. 
Pocock, J.G.A. (1985). "State of the Art". In Virtue, Commerce, and History. Cambridge: Cambridge University Press

Reiss, J. (2000). Mathematics in economics: Schmoller, Menger and Jevons. Journal of Economic Studies, 27(4/5), 477-491.

Robbins, L. (1932/1935). An Essay on the Nature and Significance of Economic Science, London: MacMillan.

Ross, D. (2003). “Changing Contours of the Social Science Disciplines” In: Ross, D. and Porter, T. The Cambridge History of Science. The Modern Social Sciences (Vol. VII). Cambridge: Cambridge University Press.

Schmoller, G. (1873) “Menger, Dr. Carl, Principles der Volkswirthschafslehre. Literarisches Zentralblatt, 5, 1. Translation by T. Caldwell in: Caldwell (2004), pp. 407-408.

Schmoller, G. (1883). "Die Schriften von K. Mengers und W. Dilthey zur Methodologie der Staats- und Socialwissenchaften" In: des. Zur Literaturgeschichte der Staats- und Sozialwissenschaften. Leipzig: Duncker \& Humblot. Partial translation in: Small, A. (1924) Origins of Sociology, Chicago: University of Chicago Press.

Schmoller, G. (1884). “Menger, Dr. Karl: Die Irrthümer des Historismus in der deutschen Nationalökonomie. Wien 1884 hölder. 8. 87 S.” Jahrbuch Für Gesetzgebung, Verwaltung Und Volkswirtschaft Im Deutschen Reich, 8. 
Schumpeter, J.A. (1954/1981). History of Economic Analysis. London: Routledge.

Screpanti, E. and Zamagni, S. (2007). An Outline of the History of Economic Thought. Oxford/New York: Oxford University Press.

Semenova, A. (2014). Carl Menger's theory of money's origins: Responding to revisionism. The European Journal of the History of Economic Thought, 21: 107-141.

Siclovan, D. (2015). Lorenz Stein and German Socialism 1835-1872. PhD Dissertation. University of Cambridge.

Skinner, Q. (1969). Meaning and Understanding in the History of Ideas. History and Theory 8 (1): 3-53.

Streissler, E. W. (1972). “To what Extent was the Austrian School Marginalist?”, History of Political Economy, 4 (2): 426 - 441.

Streissler, E.W., and K. Milford. (1993). "Theoretical and Methodological Positions of German Economics in the Middle of the Nineteenth Century" History of Economic Ideas $1: 43-79$.

Tribe, K. (2007) Strategies of Economic Order: German Economic Discourse, 1750-1950. (Ideas in Context, no. 33.) Cambridge and New York: Cambridge University Press.

Vaughn. K. (1990) 'The Mengerian roots of the Austrian revival' In: Caldwell, B. (ed) 
Carl Menger and His Legacy in Economics (379-407). Durham: Duke University

Wagner, R. (2010). 'Change within permanence’ In: Koppl, R., Horwitz, S. and Desrochers, P. (ed) What is so Austrian about Austrian Economics. (181 - 203) Bingley: Emerald Group Publishing Limited.

Wallerstein, I. (2011). The Modern World-System IV: Centrist Liberalism Triumphant, 17891914. Berkeley: University of California Press.

Wasserman, J. (2019). The Marginal Revolutionaries. New Haven: Yale University Press.

Wieser, F. (1891) The Austrian School and the Theory of Value. The Economic Journal, 1: $108-121$.

Winch, D. (1972). "Marginalism and the Boundaries of Economic Science”, History of Political Economy, 4 (2): 326-343. 